DOI: $10.35619 /$ iiu.v1i10.159

Мороз-Рекотова Леся

аспірант, асистент кафедри дошкільної освіти Бердянського державного педагогічного університету,

м. Бердянськ, Україна

ORCID: 0000-0001-5161-721X

e-mail: lesamorozrekotova@gmail.com

\title{
СУЧАСНІ ПЕДАГОГІЧНІ ТЕХНОЛОГІЇ НАВЧАННЯ ЯК ЗАСІБ ФОРМУВАННЯ ПРОФЕСІЙНО-КОМУНІКАТИВНОЇ КУЛЬТУРИ МАЙБУТНІХ ВИХОВАТЕЛІВ ЗАКЛАДІВ ДОШКІЛЬНОЇ ОСВІТИ
}

\begin{abstract}
Анотація. У статті подано етапність процесу формування професійнокомунікативної культури майбутніх вихователів закладів дошкільної освіти (мотиваційний, змістово-перетворювальний та діяльнісний), розкрито спрямованість кожного етапу, взаємообумовленість змістово-перетворювального та діяльнісного етапів на засадах вітагенного навчання. Спецкурс «Професійно-комунікативна культура вихователя закладу дошкільної освіти» визначено опосередкованим компонентом, що визначає зміст освіти та постає інтегрованим доповненням до обов'язкових дисциплін загальної, професійної та практичної підготовки, вибіркових навчальних дисциплін.

Схарактеризовано можливості застосування сучасних педагогічних технологій навчання у процесі формування професійно-комунікативної культури майбутніх вихователів закладів дошкільної освіти: когнітивно-орієнтовані (когнітивна технологічна модель «Критеріально-орієнтоване навчання», технологія командного навчання), технології ігрової взаємодії в освітньому процесі закладу вищої освіти (рефлексивні технології зняття стереотипів та формування інноваційного мислення, ділові та рольові навчальні ігри), діяльнісно-орієнтовані (мікротренінг), особистісноорієнтовані технології («соціодрама», тьюторинг). Визначено особливість мікротренінгу, яка полягає в розкладанні складної бажаної поведінки - прояву професійно-комунікативної культури - на послідовність простих умінь, розкрито структуру, яку складають три фази (навчання, тренування та зворотного зв'язку). Обгрунтовано доцільність та ефективність тьюторингу й коуч-сесій у цьому процесі. Окреслено головне завдання тьютора, що полягає у формуванні професійної суб'єктності, здатної до власного майбутнього професійного саморуху, специфіку проведення коуч-сесій із обговорення результатів самоактуалізації професійнокомунікативної культури кожним здобувачем вищої освіти. Розкрито особливості та можливості застосування голографічного методу проєкції.

Ключові слова: сучасні технології, тьюторинг, вітагенне навчання, голографічний метод проєкції, коуч-сесія.
\end{abstract}

Постановка проблеми. Реформи, які охопили й вищу освіту України, обумовлюють нагальні вектори руху в підготовці майбутніх фахівців, зокрема дошкільної освіти. Розуміючи професійно-комунікативну культуру майбутнього вихователя закладу дошкільної освіти як інтегральне динамічне особистісне утворення, що охоплює систему загальнолюдських та професійних цінностей, мовленнєвих та етичних знань, комунікативних умінь і якостей, зразків мовленнєвої поведінки, норм і правил здійснення комунікативної діяльності, які проектуються особистістю у професійну діяльність адекватно меті та завданням і забезпечують високу іiі ефективність, дійшли висновку про необхідність використання комплексу традиційних та сучасних педагогічних технологій навчання в процесі іiї формування. 
Таке переконання грунтувалось на тому, що професійно-комунікативна культура - це одна 3 форм творчої самореалізації майбутнього фахівця. Успішне іiі формування відбуватиметься за наявності самоорганізації особистості.

Аналіз останніх досліджень 3 проблеми. Серед досліджень, присвячених проблемам підготовки майбутніх фахівців дошкільної освіти особливої уваги заслуговують ті, що своїм предметом мали формування професійної культури майбутнього вихователя (Коновалова, 2018, Смолянко, 2018), формування професійної компетентності (Бєлєнька, 2006, Кідіна, 2012), увиразнення мовлення майбутніх вихователів (Руденко, 2016), формування риторичної культури (Тарасова, 2012), формування професійної майстерності (Швець, 2016), розвиток спостережливості (Цибуляк, 2015).

Проте процес, засоби, форми та методи формування професійно-комунікативної культури майбутніх вихователів закладів дошкільної освіти в полі зору науковців досі не були.

Мета статті - розкрити можливості застосування сучасних педагогічних технологій у процесі формування професійно-комунікативної культури майбутніх вихователів закладів додшкільної освіти.

Виклад основного матеріалу дослідження. Формування професійнокомунікативної культури (ПКК) майбутніх вихователів закладів дошкільної освіти (ЗДО) проходить три етапи: мотиваційний, змістово-перетворювальний та діяльнісний. Останні два - взаємообумовлюють один одного. Мотиваційний етап спрямовано на мотивацію майбутніх вихователів закладів дошкільної освіти до оволодіння ПКК. Змістово-перетворювальний - на здобуття інтегративної системи знань, яка охоплює лінгвістичний, психологічний та педагогічний аспекти професійного спрямування й містить такі напрями: 1) сучасні норми українського літературного мовлення; 2) основи комунікативної лінгвістики; 3) особливості професійно-педагогічної комунікації; 4) культура міжособистісних стосунків; 5) педагогічна етика; 6) психологія спілкування.

Беручи до уваги загальноприйняте бачення щодо єдності змістового та процесуального компонентів освітньої системи (цілей, змісту, методів, форм та засобів навчання), прояву різного ступеня консерватизму цих компонентів у процесі вдосконалення та варіювання технологій освіти (частіше варіюються процесуальні аспекти навчання, а змістові змінюються лише за структурою, дозуванням, логікою), взаємозв'язок та адекватне відображення цими компонентами один одного, опосередкованим компонентом, що визначає зміст освіти, процесуальну частину та впливає на реалізацію єдності змістового та процесуального компонентів, обрано розробку спецкурсу «Професійно-комунікативна культура вихователя закладу дошкільної освіти». Він постає інтегрованим доповненням до:

- обов'язкових дисциплін:

- загальної підготовки («Українська мова (за професійним спрямуванням)»);

- професійної та практичної підготовки («Психологія», «Культура мовлення та виразне читання», «Дошкільна лінгводидактика, культура мовлення та виразне читання»);

- вибіркових навчальних дисциплін («Педагогічна психологія», «Вікова психологія», «Тренінг розвитку спостережливості», «Основи педагогічної майстерності»).

Діяльнісний етап спрямовано на практичну (професійну) реалізацію осягнутого змісту в умовах аудиторних занять та виробничої практики. На виході з цього етапу передбачається певний рівень сформованості ПКК майбутніх вихователів ЗДО, який визначає ступінь активності здобувача, його наполегливість, працездатність, прагнення до саморозвитку. Взаємообумовленість цих етапів розкривають засади вітагенного навчання. Модель вітагенного навчання подано на рис. 1.1. 
Як зазначає Л. Мартинець, «вітагенне навчання передбачає перехід вітагенної інформації у вітагенний досвід, що має три стадії: первинне сприйняття, ціннісну фільтрацію інформації, настановчу» (Мартинець, 2015). На останній стадії, інформація, що стала надбанням особистості, відкладається в резервах довготривалої пам'яті й знаходиться у стані постійної готовності до актуалізації в адекватних ситуаціях (компетентності). Вітагенне навчання знаходить свою реалізацію у так званому голографічному методі проєкції.

На основі цієї моделі було визначено сучасні педагогічні технології навчання, форми та методи формування ПКК майбутніх вихователів ЗДО.

Тож, до сучасних педагогічних технологій навчання віднесено такі:

1. Когнітивно-орієнтовані технологї:

1) когнітивна технологічна модель «Критеріально-орієнтоване навчання», сутність якої полягає у чіткій інструментальній спрямованості (табл. 1.1);

2) технологія командного навчання (робота в парах, групами, підгрупами над однією професійно-комунікативною проблемою).

Таблиця 1.1

Когнітивна технологічна модель «Критеріально-оріснтоване навчання»

\begin{tabular}{|c|c|c|c|}
\hline $\begin{array}{c}\text { Три рівня засвосння } \\
\text { знань }\end{array}$ & $\begin{array}{l}\text { Спецкурс «Професійно- } \\
\text { комунікативна культура } \\
\text { вихователя ЗДО» }\end{array}$ & $\begin{array}{l}\text { Практична } \\
\text { діяльність }\end{array}$ & $\begin{array}{l}\text { Самостійна } \\
\text { робота }\end{array}$ \\
\hline $\begin{array}{l}1 \text { - ознайомлення, } \\
\text { розмежування } \\
\text { (діяльність спрямована } \\
\text { на розпізнавання) }\end{array}$ & $\begin{array}{l}\text { лекції: інформативні лекції- } \\
\text { візуалізації, лекції-з розбором } \\
\text { конкретних ситуацій, лекції- } \\
\text { бесіди, класична }\end{array}$ & ' & 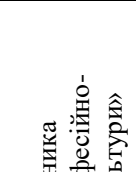 \\
\hline $\begin{array}{l}2 \text { - алгоритмічний } \\
\text { (самостійне виконання } \\
\text { алгоритмічної дії на } \\
\text { основі здобутих знань) }\end{array}$ & $\begin{array}{l}\text { практичні заняття, самостійна } \\
\text { робота, індивідуальна робота, } \\
\text { коуч-супровід }\end{array}$ & \multirow{2}{*}{ 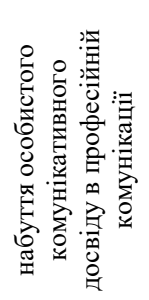 } & 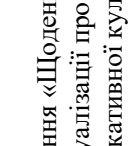 \\
\hline $\begin{array}{l}3 \text { - творчий (вирішення } \\
\text { не типових завдань на } \\
\text { основі здобутих знань) }\end{array}$ & $\begin{array}{l}\text { практичні заняття, коуч- } \\
\text { супровід, виробнича практика }\end{array}$ & & 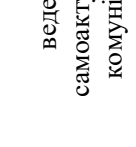 \\
\hline
\end{tabular}

Сутність технології командного навчання полягає у тому, що здобувачі працюють парами або групами над однією професійно-комунікативною проблемою (тобто вирішення професійно-комунікативних задач). Як зазначає Т. Швець, «основними елементами постають позитивна взаємозалежність, невимушене заохочення взаємодій, індивідуальна звітність, навички міжособистісного спілкування та спілкування у малих групах, обговорення досягнутого» (Швець, 2016).

2. Технології ігрової взаємодії в освітньому прочесі 3 ВО:

1) рефлексивні технології зняття стереотипів та формування інноваційного мислення;

2) ділові та рольові навчальні ігри. 


\section{Вітагенне навчання}

Суть: засноване на актуалізації життєвого досвіду особистості, інтелектуальнопсихологічного потенціалу в освітніх цілях.

\begin{tabular}{|c|c|}
\hline Вітагенна інформація (досвід життя) & Вітагенний (життєвий) досвід \\
\hline $\begin{array}{l}\text { інформація, що не прожита людиною } \\
\text { особисто, пов'язана лише з її } \\
\text { поінформованістю про ті чи інші } \\
\text { сторони життя й діяльності, проте не } \\
\text { має для неї достатньої цінності (ЗУНи). }\end{array}$ & $\begin{array}{l}\text { інформація, що стала надбанням } \\
\text { особистості, відкладена в резервах } \\
\text { довготривалої пам'яті й знаходиться у стані } \\
\text { постійної готовності до актуалізації в } \\
\text { адекватних ситуаціях (компетентності). }\end{array}$ \\
\hline
\end{tabular}

\begin{tabular}{l|l|l|}
\multicolumn{3}{c|}{ Перехід вітагенної інформації у вітагенний досвід } \\
\hline \multicolumn{1}{|c|}{$\mathbf{1}$ стадія }
\end{tabular}

Операційний. Установка на слабке запам'ятовування інформація має найменше значення для самореалізації особистості в освітньому процесі. Запам'ятовування «про всяк випадок».

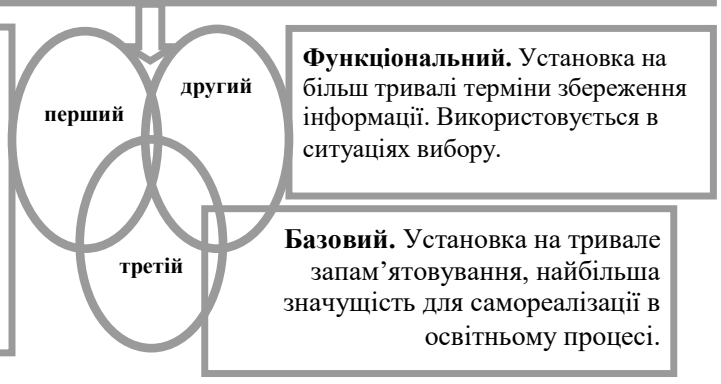


У рефлексивних технологіях зняття стереотипів та формування інноваційного мислення можна виокремити такі кроки: пошук нових ідей; формування нововведення; реалізація нововведення; закріплення нововведення.

Перший крок - пошук нових ідей передбачає формування інформативної бази в рамках спецкурсу «Професійно-комунікативна культура вихователя ЗДО», актуалізацію професійних проблем (на основі отриманого здобувачами підчас виробничої практики досвіду), створення образу майбутнього фахівця, власного професійного образу, попередню роботу 3 формулювання особистих цілей щодо роботи над власною ПКК.

Наступний крок - формування ПКК. Він містить моделювання ситуацій професійного спілкування та вправляння у застосуванні набутої інформативної бази, вибір оптимальних для особистості на цьому етапі способів прояву ПКК.

Крок реалізації сформованої ПКК (для кожного здобувача свій рівень) передбачає забезпечення умов для рефлексії, корекції способів. Цього досягають у ході виробничої практики на базі ЗДО та участі у коуч-сесіях 3 викладачем, що забезпечують акмеологічний супровід та вплив на процес формування ПКК майбутнього вихователя ЗДО.

Крок закріплення набутого досвіду являє собою закріплення образу Япрофесіонала у свідомості. Лейтмотив усіх чотирьох кроків - розвиток сприйнятливості до нового і суб'єктного ставлення до освоюваного нововведення форм прояву ПКК.

Ділові та рольові навчальні ігри широко застосовують у сучасній практиці вищої освіти. Різниця між ними полягає у тому, що в рольових навчальних іграх учасники програють будь-який сюжет із життя навколо або уявний, а в ході ділової - сюжет пов’язаний з майбутньою професійною діяльністю.

Утвердилася думка, що такі ігрові технології дають змогу полегшити процес засвоєння програмового матеріалу, активізувати навчальну діяльність, формулювати власну думку, правильно іï висловлювати, додавати свою думку, аргументувати й дискутувати, моделювати різні ситуації та збагачувати власний професійнокомунікативний досвід через включення в різні комунікативні ситуації, вчитися слухати іншу людину, поважати альтернативну думку, прагнути до діалогу, налагоджувати конструктивні відносини зі співрозмовником, визначати своє місце в діалозі, уникати конфліктів, шукати компроміси тощо.

3. Діяльнісно-орієнтовані технологї: мікротренінг (одноразовий тренінг). Змістовий компонент моделі дослідження містить різні інформативні блоки, інтеграція яких забезпечує формування ПКК майбутніх вихователів ЗДО. Мікротренінги можуть бути скомпоновані у цілісну систему (так званий «тренінг-марафон»), у якій кожен наступний логічно витікає 3 попереднього, закріплює та розвиває рівень як у змістовному плані, так і в плані вияву здібностей здобувачів, створення умов для їх реалізації.

П. де Вріс та С. Бралл зазначають, що «мікротренінги постають механізмом підтримки розвитку неформальної освітньої діяльності» (De Vries та Brall, 2008). За переконанням У. Зеебахера «мікротренінг не замінює формальне навчання», проте постає методом обміну знаннями та використання досвіду всіх учасників, що економить час (Seebacher, 2012).

Особливість мікротренінгу полягає у розкладанні складної бажаної поведінки прояву ПКК - на послідовність простих умінь, які, після оволодіння ними та їх об’єднання, приводитимуть до ефективної реалізації цієї складної поведінки.

Цикли навчання для кожного уміння та їх подальшої інтеграції у складну поведінку мають однакову структуру, що містить три основні фази: навчання, тренування та зворотного зв'язку. Фаза навчання передбачає навчання визначенню, реалізації та (часто) оцінюванню цільового вміння, фаза тренування - виконання здобувачами невеликих завдань (від 5 до 10 хв.), пов'язаних 3 тренуванням уміння у 
змодельованій ситуації (рольова гра, професійно-комунікативна ситуація тощо), а заключна фаза передбачає зворотний зв'язок, який допомагає здобувачеві покращити реалізацію набутого вміння. Акцент роблять на ефективній інтеграції умінь.

4. Особистісно-орієнтовані технологї:

1) «соціодрама»;

2) тьюторинг.

«Соціодрама» спрямована на формування механізмів особової перцепції ідентифікації, рецепції та емпатії, оскільки предметом соціодрами постають міжособистісні стосунки та індивідуальні системи їх проявів. Соціодраму широко використовують в ділових іграх. Як ігровий імітаційний метод, вона дозволяє «зазирнути» в глибини життєвої проблеми, типової для багатьох, та побачити там відображення власних відчуттів та переживань. Цією проблемою в рамках розробленого спецкурсу постає професійно-комунікативна ситуація як взаємодія двох і більше комунікантів.

Тьюторство, на переконання А. Бойко, це «індивідуально соціальна діяльність, яка сприяє подоланню суперечності між самостійним творенням власного образу й образу за наслідуванням зразків культури. У цьому випадку ідея тьюторства розуміється дослідницею як творчий пошук (співробітництво і співтворчість) у процесі взаємодії двох суб'єктів навчання і виховання» (Бойко, 2010).

Виходячи 3 досліджень М. Ро, К. Вукеліч (Roe та Vukelich, 2001), Б. Сакс (Sax, 2002), розуміємо тьютора як викладача, який здійснює підтримку освітньої діяльності здобувача з урахуванням особливостей їх особистості, життя та поведінки. У якості найвагоміших виокремлюють такі функцій тьюторської діяльності: формування індивідуальної освітньої траєкторії та психологічна підтримка здобувачів 3 урахуванням особливостей їх особистості та поведінки у метадисципліні (спецкурс «Професійно-комунікативна культура вихователя закладу дошкільної освіти»).

Як зазначає А. Бойко, головним завданням тьютора постає «формування професійної суб'єктності, здатної до власного майбутнього професійного саморуху, самоздійснення в професії завдяки своєму природному ресурсу і здобутому в процесі розвитку» (Бойко, 2010). Тоді роль тьютора полягає у забезпеченні здобуття знань, як особистісно значущих, чого досягають через суб'єкт-суб'єктні, морально-естетичні взаємини співробітництва і співтворчості.

Цінним для нас $є$ й бачення дослідниці щодо основних функцій тьютора, серед яких послуговуємося такими: «1) організаційне керівництво освітньо-пізнавальною діяльністю здобувача; 2) визначення його можливостей та інтересів; 3) рекомендації в особистісному становленні, організації самовиховання, формування способу життя, визначення особистісних перспектив; 4) надання допомоги в правильному й ефективному використанні навчально-методичного супроводу» (Бойко, 2010).

Зазначені технології реалізовують у формі лекцій, практичних занять, самостійної та індивідуальної роботи, коуч-супроводу 3 використанням інформаційнорецептивного, репродуктивного, проблемного методів, голографічного методу проєкції (рис. 1.2).

Детальніше опишемо коуч-супровід та голографічний метод проєкції.

Коуч-супровід - це форма наставництва та акмеологічного супроводу, що передбачає спеціальне алгоритмічне обговорення, спрямоване на розвиток та вдосконалення особистості. Таке обговорення забезпечує чіткість, облік та узгодженість думок і поглядів обох сторін (коуча та здобувача). Структура коуч-сесії (зустрічі у будь-якому форматі - особиста чи із застосуванням девайсів) сформована таким чином, щоб регулювати процес рефлексії та усвідомлення нового досвіду як частини себе.

Послуговуємось позицією О. Кривильової щодо необхідної «наявності у майбутнього фахівця компетентнісного, акмеологічного та аксіологічного 
цілепокладання» (Кривильова, 2018), яке, на нашу думку, постає підгрунтям для ефективного проведення коуч-сесії.

Визначена структура коучингу містить три етапи, до яких увійшли: початок коучсесії, де з'ясовують тривалість зустрічі та уточнюють зміст (яке із завдань «Щоденника самоактуалізації ПКК» буде обговорюватись); огляд/підтвердження результатів, на якому відбувається обговорення змісту «Щоденника»; завершення коуч-сесії, де акцентується на відчуття прогресу, досягнутого в ході сесії та завершують зустріч.

У ході коуч-сесії уникають настанов та рекомендацій. Коуч, ставлячи запитання, підводить до розуміння чи усвідомлення шляхів чи засобів вирішення існуючих питань (проблем). На другому етапі коуч-сесії коуч ставить запитання, робить паузи, резюмує сказане, доки не прозвучать «ключові» факти, що роз'яснюють ситуацію (наприклад, «Що стало причиною цієї ситуації?», «Чи підтримують вихователі?», «У чому полягає проблема насправді?» тощо). Для стимулювання саморозвитку здобувача корисно ставити запитання на зразок: «Що збираєтесь робити у такому випадку?», «Що відбудеться у разі застосування цієї комунікативної технології?», «Як Ви залагодите цю ситуацію?», «Що Ви можете зробити, аби виправити ситуацію?» тощо.

Проте у разі низьких показників розвитку або наявних труднощів у застосуванні конкретних комунікативних технік, коуч може запропонувати своє бачення або рішення ситуації (наприклад, «Хочу дещо Вам запропонувати...», «Можливо, є інше рішення...» тощо). Однак не варто зловживати цим прийомом, щоб не гальмувати саморозвиток здобувача.

Голографічний метод проєкції - це об'ємне оволодіння знаннями, що забезпечує реалізацію вітагенної освіти у процесі співпраці. Вітагенна проєкція - вітагенна інформація здобувачів, затребувана викладачем у процесі навчання для підготовки до викладу нового знання. Тут розгортається вектор: здобувач - знання - викладач. Джерелом вітагенної інформації постають ЗМІ, наукова, педагогічна, психологічна, методична, художня література, твори мистецтва, соціальне, професійне, побутове спілкування, різні види діяльності, освітній процес. Саме вони складають основний зміст вітагенної інформації. Концентруючись на полюсах успіху-неуспіху, досягнень та помилок, проходячи певні стадії, вітагенна інформація трансформується у вітагенний (життєвий) досвід.

Голографічна (або конструювальна) проєкція - інформація, що йде від будь-якого джерела: вітагенний досвід інших, книга, ЗМІ, твори мистецтва, наукові дані, зустрічі зі спеціалістами тощо, що створює цілісну голографічну картину знання.

Дидактична або стереопроєкція - це наукова інформація, що йде від викладача, який використовує вітагенну інформацію здобувачів. Тоді постає такий вектор: викладач - знання - здобувач. 
це система освітніх способів, технологій у навчанні, спрямована на об’ємну багатомірну подачу досліджуваного матеріалу, що відповідає особливостям багатомірності сприйняття навколишнього світу й запасу життєвого досвіду. Поняття голографії - фізичне. Означає розгляд об’єкта у відбитому багатомірному просторі, не менш ніж у трьох проєкціях:

$\begin{array}{lll}\begin{array}{l}\text { Вітагенна проєкція - } \\ \text { вітагенна інформація }\end{array} & \begin{array}{l}\text { Голографічна } \\ \text { (конструювальна) }\end{array} & \begin{array}{l}\text { Стереопроєкція } \\ \text { здобувактична) - наукова }\end{array} \\ \text { викладачем у процесі } & \text { проєкція - } & \text { інформація, що йде від } \\ \text { навчання для підготовки до } & \text { інформація, що } & \text { викладача. } \\ \text { викладу нового знання. } & \text { якого } & \text { Вектор: викладач - } \\ \text { Вектор: здобувач - знання - } & \text { додаткового } & \end{array}$

Рис. 1.2. Суть голографічного методу проєкції

Висновки і перспективи подальших розвідок. Високий рівень сформованості ПКК майбутніх вихователів ЗДО значною мірою залежить від застосовуваних у цьому процесі засобів, форм та методів. У процесі нашого дослідження з'ясовано широкі можливості застосування сучасних педагогічних технологій навчання (когнітивноорієнтовані, ігрової взаємодії в освітньому процесі ЗВО, діяльнісно-орієнтовані, особистісно-орієнтовані). Їх комплексне застосування забезпечуватиме ефективність процесу формування професійно-комунікативної культури майбутніх вихователів закладів дошкільної освіти.

Перспективи подальших розвідок вбачаємо у розробці системи практичних занять з формування ПКК з майбутніми фахівцями дошкільної освіти.

\section{СПИСОК ВИКОРИСТАНИХ ДЖЕРЕЛ}

Коновалова, К. (2018). Формування професійної культури майбутніх вихователів закладів дошкільної освіти у прочесі фахової підготовки. Кандидат педагогічних наук. Державний заклад «Південноукраїнський національний педагогічний університет імені К. Д. Ушинського».

Смолянко, Ю. (2018). Формування професійної культури майбутніх фахівців дошкільної освіти у прочесі магістерської підготовки. Кандидат педагогічних наук. Національний університет «Чернігівський колегіум» імені Т. Г. Шевченка.

Бєлєнька, Г. (2006). Вихователь дітей дошкільного віку: становлення фахівия в умовах навчання: монографія. Київ: Світич, 2006. 304 с.

Кідіна, Л. (2012). Формування професійної компетентності майбутніх вихователів дошкільних навчальних закладів у процесі педагогічної практики. Кандидат педагогічних наук. Слов'янський державний педагогічний університет.

Руденко, Ю. (2016). Теоретико-методичні засади розвитку виразного мовлення майбутніх вихователів дошкільних навчальних закладів. Доктор педагогічних наук. Державний заклад «Південноукраїнський національний педагогічний університет імені К. Д. Ушинського».

Тарасова, В. (2012). Формування риторичної культури майбутніх фахівців дошкільних навчальних закладів. Кандидат педагогічних наук. Харківський національний педагогічний університет імені Г. С. Сковороди. 
Швець, Т. (2016). Педагогічні умови формування професійної майстерності майбутніх вихователів дошкільних навчальних закладів. Кандидат педагогічних наук. Херсонський державний університет.

Цибуляк, Н. (2015). Розвиток спостережливості майбутніх вихователів дошкільних навчальних закладів: теоретико-практичні аспекти: монографія. Бердянськ: Видавець Ткачук О. В., 2015. 288 с.

Мартинець, Л. (2015). Сучасні моделі освіти. Вид. 2-ге, переробл. і допов. Донецьк, 2015. 102 с.

De Vries, P. and Brall, S. (2008). Microtraining as a support mechanism for informal learning. eLearning Papers, [pdf] Volume 11, November. [online]. Режим доступу: https://www.oei.es/historico/tic/media17532.pdf [Дата звернення 13 липня 2018].

Seebacher, U. (2012). Microtraining sustainable lifestyle. The Microtraining method [online]. $\quad$ [pdf] Режим доступу: http://www.sustainicum.at/files/tmethods/20/en/additional/Microtraining\%20Method_en.pdf. [Дата звернення 13 липня 2018].

Бойко, А. (2010). Тьюторство як засіб задоволення освітніх потреб особистості, країни і суспільства. Педагогічні науки, 1. с. 4-11.

Roe, M. and Vukelich, C. (2001). Understanding the Gap between an AmericaReads Program and the Tutoring Sessions The Nesting of Challenges. Journal of Research in Childhood Education, [online] 16 (1). p. 39-52.

Sax, B. (2002). Brief Report: New Roles for Tutors in an Online Classroom. Journal of College Reading and Learning, [online] 33 (1). pp. 62-67.

Кривильова, О. (2018). Проектування психолого-педагогічної підготовки майбутніх викладачів професійно-технічних навчальних закладів. Доктор педагогічних наук. Бердянський державний педагогічний університет.

\section{REFERENCES}

Konovalova, K. (2018). Formuvannia profesiinoi kultury maibutnikh vykhovateliv zakladiv doshkilnoi osvity u protsesi fakhovoi pidhotovky [Formation of Professional Culture in Future Preschool Teachers in the Process of Professional Training]. Kandydat pedahohichnykh nauk. Derzhavnyi zaklad "Pivdennoukrainskyi natsionalnyi pedahohichnyi universytet imeni K. D. Ushynskoho". (in Ukrainian)

Smolianko, Yu. (2018). Formuvannia profesiinoi kultury maibutnikh fakhivtsiv doshkilnoi osvity u protsesi mahisterskoi pidhotovky [Formation of Professional Culture in Future Specialists of Preschool Education in the Process of Master's Preparation]. Kandydat pedahohichnykh nauk. Natsionalnyi universytet "Chernihivskyi kolehium" imeni T. H. Shevchenka. (in Ukrainian)

Bielienka, H. (2006). Vykhovatel ditei doshkilnoho viku: stanovlennia fakhivtsia $v$ umovakh navchannia [Teacher of Preschool Children: Formation a Specialist in the Conditions of Training]. Kyiv: Svitych, 2006. 304 s. (in Ukrainian)

Kidina, L. (2012). Formuvannia profesiinoi kompetentnosti maibutnikh vykhovateliv doshkilnykh navchalnykh zakladiv u protsesi pedahohichnoi praktyky [Formation of Professional Competence of Future Preschool Teachers in the Process of Pedagogical Practice]. Kandydat pedahohichnykh nauk. Slovianskyi derzhavnyi pedahohichnyi universytet. (in Ukrainian)

Rudenko, Yu. (2016). Teoretyko-metodychni zasady rozvytku vyraznoho movlennia maibutnikh vykhovateliv doshkilnykh navchalnykh zakladiv [Theoretical and Methodological Foundations of the Development of Expressive Speech in Future Preschool Teachers]. Doktor pedahohichnykh nauk. Derzhavnyi zaklad "Pivdennoukrainskyi natsionalnyi pedahohichnyi universytet imeni K. D. Ushynskoho". (in Ukrainian)

Tarasova, V. (2012). Formuvannia rytorychnoi kultury maibutnikh fakhivtsiv doshkilnykh navchalnykh zakladiv [Formation of Rhetorical Culture in Future Specialists of Ppreschool Educational Institutions]. Kandydat pedahohichnykh nauk. Kharkivskyi natsionalnyi pedahohichnyi universytet imeni H. S. Skovorody. (in Ukrainian) 
Shvets, T. (2016). Pedahohichni umovy formuvannia profesiinoi maisternosti maibutnikh vykhovateliv doshkilnykh navchalnykh zakladiv [Pedagogical Conditions for the Professional Skills Formation of Future Preschool Teachers]. Kandydat pedahohichnykh nauk. Khersonskyi derzhavnyi universytet. (in Ukrainian)

Tsybuliak, N. (2015). Rozvytok sposterezhlyvosti maibutnikh vykhovateliv doshkilnykh navchalnykh zakladiv: teoretyko-praktychni aspekty [Observational Development in Future Preschool Teachers: Theoretical and Practical Aspects: monohraph]. Berdiansk: Vydavets Tkachuk O. V., 2015. 288 s. (in Ukrainian)

Martynets, L. (2015). Suchasni modeli osvity [Modern Models of Education]. Vyd. 2-he, pererobl. i dopov. Donetsk, 2015. 102 s. (in Ukrainian)

De Vries, P. and Brall, S. (2008). Microtraining as a support mechanism for informal learning. eLearning Papers, [pdf] Volume 11, November. [on line]. Rezhym dostupu: https://www.oei.es/historico/tic/media17532.pdf [Data zvernennia 13 lypnia 2018].

Seebacher, U. (2012). Microtraining sustainable lifestyle. The Microtraining method/ [online]. [pdf]. Rezhym dostupu: http://www.sustainicum. at/files/tmethods/20/en/additional/Microtraining\%20Method_en.pdf. [Data zvernennia 13 lypnia 2018].

Boiko, A. (2010). Tiutorstvo yak zasib zadovolennia osvitnikh potreb osobystosti, krainy i suspilstva [Tutoring as a Means of Satisfaction the Educational Needs of the Individual, Country and Society]. Pedahohichni nauky, 1. s. 4-11. (in Ukrainian)

Roe, M. and Vukelich, C. (2001). Understanding the Gap between an AmericaReads Program and the Tutoring Sessions The Nesting of Challenges. Journal of Research in Childhood Education, [online] 16 (1). p. 39-52.

Sax, B. (2002). Brief Report: New Roles for Tutors in an Online Classroom. Journal of College Reading and Learning, [online] 33 (1). p. 62-67.

Kryvylova, O. (2018). Proektuvannia psykholoho-pedahohichnoi pidhotovky maibutnikh vykladachiv profesiino-tekhnichnykh navchalnykh zakladiv [Designing of Psychological and Pedagogical Training in Future Teachers of Vocational Schools]. Doktor pedahohichnykh nauk. Berdianskyi derzhavnyi pedahohichnyi universytet. (in Ukrainian)

\title{
MODERN PEDAGOGICAL TECHNOLOGIES OF LEARNING AS A MEANS OF FORMING THE PROFESSIONAL AND COMMUNICATIVE CULTURE IN FUTURE PRESCHOOL TEACHERS
}

\author{
Lesia Moroz-Rekotova \\ Postgraduate, Assistant at the Department of Preschool Education, \\ Berdiansk State Pedagogical University \\ Berdiansk, Ukraine \\ ORCID: 0000-0001-5161-721X \\ e-mail: lesamorozrekotova@gmail.com
}

\begin{abstract}
The article presents the stages of the process of forming the professional and communicative culture in future preschool teachers (motivational, content-transformative and activity), the orientation of each stage, the interdependence of content-transformative and activity stages on the basis of vitagenic training are revealed. The special course "Professional and communicative culture of a preschool teacher" is defined as an indirect component that defines the content of education and becomes an integrated addition to the compulsory disciplines of general, vocational and practical training, selective educational disciplines.

Possibilities of modern pedagogical teaching technologies' application in the process of professional and communicative culture formation in future preschool teachers are characterized: cognitive-oriented (cognitive technological model "Criterion-oriented training", technology of team education), technologies of game interaction in the educational
\end{abstract}


process in a higher educational institution (reflexive technologies of removing stereotypes and formation of innovative thinking, business and role-playing educational games), activityoriented (micro-training), personality-oriented technologies ("sociodrama", tutoring). The peculiarity of micro-training, which is in the decomposition of complex desirable behavior manifestation of professional and communicative culture - into the sequence of simple skills, the structure of three phases (education, training and feedback) is identified. The feasibility and effectiveness of tutoring and coaching sessions in this process are substantiated. The main task of a tutor, which is to form a professional subjectivity capable of own future professional self-movement, specifics of conducting coaching sessions to discuss the results of self-actualization of the professional-communicative culture of each higher education student, is outlined. The features and possibilities of using the holographic projection method are revealed.

Keywords: modern technologies, tutoring, vitagen training, holographic projection method, coaching session.

Стаття надійшла до редакиії 24.09.2019 p. 